\title{
A INVENÇÃO DO MITO DE SEPÉ TIARAJU NA ROMARIA DA TERRA*
}

\author{
Valéria Aydos \\ Universidade Federal de Santa Maria
}

\begin{abstract}
Resumo: A Romaria da Terra é um dos tipos de peregrinação que fazem parte do calendário político-religioso do Rio Grande do Sul. Com um caráter itinerante, ocorre anualmente na Terça-feira de Carnaval - ocasião em que são discutidas questóes políticas e sociais dentro de um contexto do Catolicismo Libertador. Neste artigo, abordamos a Romaria da Terra como um espaço de ritualização das lutas pela propriedade da terra no estado, recortando como objeto central para esta análise o mito de Sepé Tiaraju, índio missioneiro que é considerado o "santo da ro maria”. Nossa hipótese é a de que os agentes da romaria, como o Movimento dos Trabalhadores Rurais Sem-Terra, a Comissão Pastoral da Terra e o Partido dos Trabalhadores, estariam construindo uma narrativa que uniria todos os atores das "lutas pela terra", no nível do simbólico, em uma única "história dos conflitos no campo", e que, ao trazer a figura do índio - o "verdadeiro dono" da terra - para o contexto ritual da romaria, esses atores estariam legitimando, de alguma maneira, o seu direito à terra.
\end{abstract}

Palavras-chave: CPT, política, romarias, Sepé Tiaraju.

Keywords: CPT, pilgrimages, policy, Sepé Tiaraju.

Entre os vários tipos de peregrinações presentes no Estado do Rio Grande do Sul, a Romaria da Terra é a mais peculiar tanto em seus significados e sentidos quanto em sua performance. Diferentemente das romarias tradici-

\footnotetext{
"Este artigo é parte de meu trabalho de conclusão no curso de bacharelado em Ciências Sociais da UFRGS, defendido em dezembro de 1999, sob orientação do professor Dr. Carlos Alberto Steil.
} 
onais, ${ }^{1}$ tem características do culto ecumênico e é inserida na Teologia da Libertação, o que faz com que seja considerada antes uma romaria política do que devocional.

Segundo Steil (1996), o que vemos na Romaria da Terra é a existência de "um espaço de indeterminação que instaura um campo de disputas e de negociação entre os discursos religioso e político. Os problemas sociais e os confrontos no campo são ritualizados através do culto e trazidos para o discurso bíblico-religioso da Libertação e do Martírio, o que nos permite falar de uma reinvenção da romaria pelo catolicismo militante que, ao mesmo tem po que se politiza, também sacraliza a política." (Steil, 1996, p. 286).

Sendo assim, não há um santuário ou local de concentração do sagrado, mas o sagrado torna-se o homem e a terra. A presença dos fiéis é coletiva e não individual; as pessoas não vão à romaria somente para agradecer ou pagar promessas, mas sim, como comenta Dona Cleusa, integrante do Movimento dos Trabalhadores Rurais Sem-Terra (MST) e assentada em Guaíba, para celebrar a "união do povo" e as "vitórias das lutas no campo". Seu José, militante do Partido dos Trabalhadores (PT), também enfatiza as diferenças entre as motivações dos participantes das romarias diocesanas daquelas dos das Romarias da Terra ao comentar que, para ele, "a romaria é um lugar para encontrar os companheiros". "Se eu viesse para rezar não trazia a bandeira'?", diz seu José.

A partir destas características da Romaria da Terra, compreendemos esse evento - onde a bandei ra substitui a imagem, ond e o que é enfocado é a "união" e a "organização" de lutas políticas e sociais - como um espaço de ritualização das lutas no campo, e, sendo assim, propomo-nos enfatizar neste artigo de que forma essas lutas, no Rio Grande do Sul, estão sendo explicitadas nesse ritual, ou mais especificamente, como os atores da Romariada Terradeste estado estariam performandoe representandouma questão que se torna central nesse contexto: a questão da propriedade da terra.

${ }^{1}$ Referimo-nos, aqui, às romarias diocesanas.

${ }^{2}$ Seu José trazia consigo a bandeira do Partido dos Trabalhadores. 


\section{O SURGIMENTO DAS ROMARIAS DA TERRA NO RIO GRANDE DO SUL}

Pode-se considerar que a partir de 1950 inicia-se a configuração de um movimento social por parte das populações rurais brasileiras. Segundo Tavares dos Santos (1989), é nesse momento que as manifestaçôes sociais no campo atingem dimensões políticas e superam as açôes localizadas. Duas organizações, em posições antagônicas, podem ser citadas como elementos demarcadores dos conflitos no campo: as ligas camponesas e os sindicatos formados pela Igreja Católica. (Santos, 1989, p. 76-77).

Em março de 1960, começa, no Rio Grande do Sul, a organização de um movimento que foi precursor do Movimento dos Trabalhadores Rurais Sem-Terra (MST), denominado MASTER (Movimento dos Agricultores Sem-Terra) e, pela primeira vez na história do Brasil meridional, aparece a categoria política do "agricultor sem terra", representando posseiros, filhos de camponesesminifundiários e até mesmo os diaristas rurais. (Santos, 1989, p. 78-82).

No final da década de 1970 presencia-se um momento de grande insatisfação com a situação do meio rural no Brasil. Como demonstram vários autores (Gehlen, 1983; Hoffman, 1997; Navarro, 1997; Santos, 1989), um grande número de trabalhadores foi excluído do acesso à terra devido ao alto grau de capitalização da atividade agrícola e à diminuição drástica de sua mão-de-obra, em conseqüência do processo de modernização no campo que teve início na metade dos anos 1960.

Nessa época, a Igreja Católica, através das Comunidades Eclesiais de Base (CEBs) e da sua cúpula hierárquica, redefine sua posição política acerca das lutas sociais. Segundo Novaes (1997), com a criação de entidades especializadas em orientação jurídica, ${ }^{3}$ a Igreja Católica introduz uma nova concepção de "direito", que se funda sobre a necessidade, ou seja, a de que

\footnotetext{
3 A Comissão Pastoral da Terra é criada nesse contexto, vindo a desempenhar papel funda-
} mental na Romaria da Terra, assim como nas lutas no campo no Rio Grande do Sul. 
a terra pertence àqueles que dela necessitam. Instaura-se, assim, o que a au tora denomina de "lei da necessidade". ${ }^{4}$

Para garantir a observância desse direito, a hierarquia católica passa a prestar seu apoio, sobretudo os bispos, à causa dos trabalhadores rurais, ao mesmo tempo em que articula uma rede de leigos predispostos a se apresentarem como "a parcela do Povo de Deus em Caminhada para a Libertação", que dá concretude a comu nidades religiosas politicamente mobilizadas e animadas pela presença de advogados/agentes de pastoral.

Multiplicam-se, então, os eventos patrocinados pelos setores da "Igreja Progressista" nas comunidades rurais. Um deles foi a criação do Conselho Indigenista Missioneiro (CIMI), que em 1975 ofereceum curso em Ijuí (RS), tendo como objetivo discutir questóes referentes à cidadania do índio.

Também em 1975, como menciona Tavares dos Santos (1989, p. 80), "reuniram-se em Goiânia padres e agentes pastorais com experiência de militância junto às populações indígenas e aos camponeses da Amazônia" para discutir problemas relacionados à questão da terra. Neste encontro foi decidida a criação da CPT, "para apoiar os homens sem terras e os trabalhadores rurais”. (Santos, 1989, p. 80).

Em 1976 começam as disputas por terras indígenas no município de Nonoai, que acabam por eclodir em um conflito entre índios e colonos, no dia 4 de maio de 1978, a partir da reação de grupos indígenas no esforço de recuperar suas terras de parceleiros que haviam sido deslocados para região por uma determinação governamental, com o objetivo de assentá-los em áreas ali existentes.

Esse conflito lança luz sobre a questão da posse das terras indígenas e da ausência de terras para os camponeses. A questão indígena é, assim, colocada "na ordem do dia", e junto com ela vem o principal problema desta população: a questão da terra. ${ }^{5}$

\footnotetext{
${ }^{4}$ Regina Novaes (1997) faz uma periodização dos conflitos no campo na Paraíba que acreditamos ser interessante trazer para o contexto do Rio Grande do Sul, com os devidos cuidados. A autora define esses conflitos em quatro momentos sucessivos, que denomina: "lei da chibata", "lei da nação", "lei do sindicato" e "lei da necessidade".

5 Sobre essa temática ver o trecho Nonoai: Indios e Colonos (Santos; Belloni; Lacroix, 1981).
} 
Em meio a esses acontecimentos, lideranças da Igreja Progressista, inseridas na Teologia da Libertação, discutem a organização de um evento para o Ano dos Mártires, o que vai dar origem à primeira Romaria da Terra. No relato de sua conversa com Pedro Casaldáliga, Antônio Cechin ${ }^{6}$ explicita o "mito de origem" da romaria:

[...] Aqui no RS, os bispos são extremamente conservadores. Eles freqüentemente mandam vir o coração do padre Roque González, que está em Assunção. Então cada vez que mandavam vir o coração do Padre Roque [...] sempre os índios eram os vilóes - eles que assassinaram os padres etc. e tal. Então eu escrevi para o Pedro Casaldáliga e ele me mandou uma carta inflamada e disse: "Antônio, os índios não podem mais ser vilóes, eles que são os mártires. Vamos proclamar o Ano dos Mártires. Ano que vem, [será] o ano dos mártires indígenas e também dos padres, porque afinal de contas, foram zelosos, abandonaram a família..." Então a gente co mbinou que neste Ano dos Mártires (que se não me engano é 1978) começaria a Romaria da Terra no dia da morte de Sepé Tiaraju. [...] ele teria morrido na terça-feira de Carnaval, dia 7 de fevereiro. [...] Em 1978 coincidia o dia com a terçafeira de Carnaval. Então nós abrimos o Ano dos Mártires com a primeira romaria, que não se chamava ainda Romaria da Terra, era Romaria aos Nossos Mártires - os índios.

Acontecia, então, a primeira Romaria da Terra em Caiboaté, na região das Missóes Jesuíticas, tendo como objetivo dar visibilidade à ação da Igreja da Libertação em favor dos índios, e também à abertura do Ano dos Mártires Rio-Grandenses.

A proposta era ter um ano de celebrações abrindo o calendário de eventos com uma peregrinação para o local do martírio dos santos jesuítas com uma via crucis e uma celebração eucarística, que ocorreu em 7 de fevereiro de 1978. A essa abertura se seguiram também outras atividades durante o

${ }^{6}$ Entrevista concedida por Antônio Cechin a Daniel Alves, bolsista de iniciação científica juntamente com Valéria Aydos, na realização da pesquisa Peregrinação e Turismo Religioso no Rio Grande do Sul, orientada pelo professor Carlos Alberto Steil , em 1999. 
mesmo ano: como a Semana do Índio, a partir de 15 de abril nas ruínas de São Miguel, cidade de Sepé e capital das Missóes, e a Festa dos Três Mártires, de 17 a 19 de novembro, que incluía a realização de um congresso missioneiro de caráter religioso-científico.

O objetivo expresso nos documentos encontrados, especialmente no convite que foi elaborado para a celebração e o texto da via crucis, era de "celebrar os 350 anos do martírio dos missioneiros jesuítas Roque González e seus companheiros Alfonso Rodrigues e Juan de Castillos; os 222 anos da morte de Sepé Tiaraju, índio que morreu assassinado em 27 de fevereiro de 1756, seus companheiros Guaranis e os 458 anos de martírio ininterrupto do povo indígena no Brasil" (CPT/RS, 1978). Esta primeira celebração tinha como lema: "A salvação do índio está na consciência do branco".

Nos documentos da CPT está expressa a preocupação dessa ala da igreja com o caráter pedagógico do culto, que é criado com o objetivo de "estimular e capacitar homens e mulheres da terra a ocupar seu espaço dentro da Igreja e colaborar para que haja um crescimento político na luta e nas organizações do campo" (CPT/RS, 1978).

Como nos demonstra Goes (1997), sob denominação da Teologia da Libertação cresceu na Igreja latino-americana uma nova concepção a respeito de seu papel. Nesse período, tomou corpo um modelo voltado às especificidades das contradiçôes sociais dos países latino-americanos, pautado pelo aprofundamento da divisão social em virtude da concentração de renda. (Goes, 1997, p. 23-27). Nesse mesmo sentido, afirma Navarro (1997, p. 22) que "os religiosos, imbuídos por esta 'nova compreensão de mundo', ofertavam uma ain da indefinida 'nova sociedade' aos agricultores, situando seu discurso entre os 'males do capitalismo' e uma vaga 'sociedade alternativa', ap resentando, assim, os caminhos para a ação social”.

Em 1981, é formado um dos maiores acampamentos do MST ao longo da estrada que une a cidade de Passo Fundo a Ronda Alta, próximo da

\footnotetext{
${ }^{7}$ Cada romaria versa em torno de um problema social que será o foco de discussóes do evento. Dependendo do tema escolhido é criado um lema que aparecerá nos folhetos, palavras de ordem do ritual, etc.
} 
cidade de Sarandi. Este foi conhecido como o acampamento da Encruzilhada Natalino, e foi formado em março desse ano, com 300 famílias. Em maio do mesmo ano já contava com aproximadamente 600 famílias, além do apoio de um grande número de religiosos.

Nesse ano, o foco central de discussão das Romarias da Terra passa do problema indígena ${ }^{8}$ (até 1981) para o dos sem-terra, e a romaria de 1982 é realizada em Encruzilhada Natalino-Sarandi, contando com a presença de 33 mil romeiros, que caminharam com o lema: "O povo unido jamais será vencido".

Como demonstra Navarro (1997, p. 49), entre 1978 e 1984 a conjuntura política mostrou-se fortemente favorável à arregimentação de agricultores sem acesso à terra ou com parcelas diminutas de terra, em especial devid o à intensa legitimação oferecida pelos setores "progressistas" da Igreja Católica e Luterana no Estado e, também, pela erosão do controle social exercido pelo último mandatário do ciclo militar.?

A história da Romaria da Terra está diretamente associada à trajetória da Comissão Pastoral da Terra (CPT) - hoje o principal núcleo da Teologia da Libertação no Estado. Este relato de Antônio Cechin nos ilustra um pouco a proposta dos religiosos da Teologia da Libertação sobre a valorização do martírio e a importância da Romaria da Terra na consolidaçáo da CPT.

Era isso que distinguia, nós íamos onde o Cristo estava sofrendo. Então [...] começamos por Sepé porque tinha o resgate dos mártires e tudo isso aí. As

\footnotetext{
${ }^{8}$ Lemas que versavam sobre a questão indígena: "A salvação do índio está na consciência do branco"; "Justiça para todos, vamos salvar a terra mãe terra"; "Alto lá, esta ter ra tem dono".

9 O último mandatário foi João Batista Figueiredo, que em 1984 presencia o fim do ciclo militar com o movimento pelas "Diret as Já", que representou o maior ato de mobilização popular contra a ditadura. Tal movimento teve como base pressionar o Congresso Nacional para aprovação da emenda constitucional Dante de Oliveira, a qual previa eleições diretas para presidente. Esta foi rejeitada por 22 votos, porém, devido à pressão popular, foi constituída a chapa Tancredo Neves e José Sarney.
} 
maiores denúncias no Brasil eram em torno dos índios. [...] Nós estávamos em busca de lutas, e só acertamos com a CPT aqui quando descobrimos os sem-terra.

Hobsbawm (1997, p. 21) nos lembra que "muitas vezes a história é utilizada como legitimadora das açôes e como cimento de coesão de um grupo. Muitas instituiçôes políticas, movimentos ideológicos e grupos sem antecessores tornaram necessária a invenção de uma continuidade histórica, por exemplo, através da criação de um passado antigo que extrapole a continuidade real seja pela lenda ou pela pura invençáo."

A Romaria da Terra, nesse sentido, pode ser tomada como um espaço no qual os atores que dela participam vislumbram a construção de sua história e tomam consciência de sua trajetória comum. Claudir, integrante do MST, também ilustra este sentimento de "união' numa "utopia", que levaria a um mesmo destino social:

[...] Eu sinto assim, que este movimento resgata toda nossa história, ele faz memória do que a gente está vivendo hoje. Este sistema que oprime, que exclui. A gente gostaria de ver acontecer a partilha do dinheiro, de tudo que tá aí, que o resto partilhe.

Pode-se dizer, então, que a Romaria da Terra é um ritual com práticas de natureza simbólica que constrói valores, ideologias e padrões de compor tamento - legitimados por esta "história inventada" - e que produz uma identidade coletiva que reúne índios, colonos sem-terra, religiosos, sindicalistas, militantes políticos e ecologistas.

Essa narrativa, construída pelos atores da romaria, possui, no nível do simbólico, também um elemento utópico: o sonho de um dia alcançarem a "Terra Prometida" - onde não haveria classes sociais, exploração, capitalismo, etc. Esta sociedade futura poderia ser compreendida, através de Turner (1974), como uma communitasideológica construída nesse ritual,pois, através dela, os sujeitos da Romaria da Terra constroem seu ideal político e social de uma sociedade que é caracterizada por uma communitas existencial. Esta, por sua vez, seria "a confrontação direta, imediata e total de identidades 
humanas que tendem a fazer dessa experiência algo pensado, homogêneo, desestruturado e de livre comunhão". (Turner, 1974, p 169, tradução minha). Um dos momentos mais significativos de nosso trabalho de campo ${ }^{10}$ nas Romarias da Terra, o qual, inclusive, foi um acontecimento-chave para elaboração deste trabalho, se deu quando retornávamos da romaria de 1999, junto a um grupo de integrantes do MST. O clima do retorno era de festa. Alguns homens tocavam violão e cantavam músicas que falavam de Sepé Tiaraju, ${ }^{11}$ Quilombo dos Palmares e outras figuras do Rio Grande do Sul. Ouvíamos nas letras das músicas que Sepé aparecia como herói que os "havia ensinado a lutar", que esse índio era "o primeiro herói das lutas no campo no Rio Grande do Sul". Questionamos a razão pela qual os colonos exaltavam a figura de Sepé Tiaraju, e estes nos responderam: "Porque ele foi quem começou toda a nossa luta".

Norteados, então, por esta "pista" de acesso ao universo simbólico do ritual, que nos dizia que Sepé era parte da história daquele grupo e também dos romeiros da terra, percebemos que nos folhetos distribuídos pela CPT em cada romaria, na performance do evento (onde a bandeira de Sepé Tiaraju era portada por um grupo de sem-terra) e também nos discursos dos participantes, existia uma noção de "união" de todos os "explorados e oprimidos da terra" numa única história. O princípio dessa história remontaria, portanto, ao martírio dos índios das Missões Jesuíticas na sua luta pela terra, representada na figura de Sepé Tiaraju, e que tem continuidade com os colonos sem-terra, representados, hoje pelo MST.

\footnotetext{
${ }^{10}$ Foram feitas observações participantes em duas romarias: em Ivorá (1998), quando acompanhamos um ônibus de romeiros da diocese de Santa Cruz, e em Jóia (1999), no assentamento Ceres, onde acompanhamos um grupo de sem-terra do assentamento de Eldorado do Sul. Foram feitas 27 entrevistas semi-abertas, com romeiros, padres e lideranças dos movimentos e organizações sociais, nos locais de realização das romarias, e elaborados diários de campo com as observaçôes do ritual como um todo.

${ }^{11}$ Segundo o folclore e a historiografia do Rio Grande do Sul, Sepé Tiaraju foi um índio missioneiro que morreu defendendo a propriedade da terra de seu povo nas Missóes Guaraníticas, na década de 1750 .
} 
Partimos, então, para uma análise mais aprofundada das "histórias" que deram origem ao mito de Sepé e de como a figura desse índio estava sendo incorporada no contexto da Romaria da Terra, tendo como hipótese que os atores presentes na romaria (CIMI, MST, CPT e PT) estariam se apropriando do mito de Sepé Tiaraju como instrumento de sua luta política e social, e também como elemento definidor de sua identidade. Acreditamos que as histórias e lendas ${ }^{12}$ sobre Sepé e sua luta pela propriedade da terra na região das Missões estão sendo incorporadas e reinventadas, ${ }^{13}$ pelos atores presentes na Romaria da Terra, como o "mito de origem" das lutas no campo de todos que hoje a vivenciam. Nessa versão do mito, Sepé torna-se, então, herói não só dos índios, mas dos colonos sem-terra e dos católicos libertadores.

\section{SEPÉ TIARAJU}

O mito de Sepé Tiaraju tem sua origem nas batalhas travadas entre os índios Guarani e os governos de Espanha e Portugal, na década de 1750.

\footnotetext{
${ }^{12}$ Nos referimos, aqui, a "h istórias" e "lendas" porque tomamos tanto a historiog rafia quanto as lendas do folclore gaúcho como narrativas que estão sendo incorporadas e ressignificadas na Romaria da Terra, no processo de invenção do mito de Sepé Tiaraju. Essas narrativas, para fins de nossa análise, servem de objeto de estudo para a compreensão desse processo. Nesse sentido, entendemos que as diferentes versôes, tanto da historiografia quanto das lendas rio-grandenses, fundem-se, no contexto da Romaria da Terra, em uma única "nar rativa mitológica" que "fornece modelos e confere significação à conduta hu mana" (Eliade, 1991, p. 11-12). Segundo Eliade, "o mito narra como, graças às façanhas dos Entes Sobrenaturais, uma realidade que passou a existir, seja uma realidade total, o Cosmo, ou apenas um fra gmento [...] é sempre a narrativa de uma 'criação': ele relata de que modo algo foi produzido e começou a 'ser'. [...] Em su ma, os mitos desc revem as diversas, e algumas vezes dramáticas, irrupçôes do sagrado que realmente fundamentam o Mundo e o convertem no que é hoje." (Eliade, 1991, p. 11-12).

${ }^{13}$ Interpretamos esse processo de reinvenção do mito de Sepé tendo como influência o conceito de Hobsbawm de "tradição inventada", "aquela que estabelece ou simboliza a coesão social ou as condições de admissão de um grupo ou de continuidades reais ou artificiais" e "aquela cujo propósito principal é a socialização, a inculcação de idéias, sistemas de valores e padrões de comportamento” (Hobsbawm, 1997, p. 17).
} 
Ruben Oliven, comentando o papel do índio na construção da identidade do gaúcho, afirma que:

No século XVII, os bandeirantes vieram no encalço dos índios, parte dos quais estavam aldeados em reduções jesuíticas. A fundação pelos jesuítas dos Sete Povos das Missões a partir de 1682 significou a criação de centros econômicos de grande importância, onde os indígenas criavam gado e plantavam erva-mate. Na medida em que eram percebidos como um "Império Teocrático na América”, os Sete Povos passaram a preocupar Portugal e Espanha e foram objeto do Tratado de Madri, em 1750, que acertou que o primeiro entregaria Sacramento ao segundo, ficando com as Missões, o que acabou motivando a "Guerrilha Guaranítica" (1754-1756) movidos pelos índios liderados por Sepé Tiaraju que não estavam dispostos a entregar suas terras. (Oliven, 1992, p. 53).

Analisando as diversas versões das narrativas de Sepé Tiaraju e o papel do índio no folclore e na historiografia do Rio Grande do Sul, são três os episódios de sua história que aparecem com maior freqüência nessas narrativas: o primeiro é a visita que o índio faz ao governador Gomes Freire de Andrade, acompanhado do seu companheiro Cacambo. Ao referir-se a esse episódio, os folcloristas, assim como os historiadores, ressaltam a bravura e a altivez de Sepé que, colocando-se acima da autoridade do governador, defende a propriedade da sua terra e a liberdade da sua gente. Ao ser ameaçado de aprisionamento, "foge com grande habilidade", demonstrando seu "sangue guarani". Sepé é aquele que conhece as florestas e domina os animais - o valente e bom selvagem.

Um dos relatos mais ricos sobre Sepé é o do padre Carlos Teschauer:

Gomes Freire convidara o chefe ameríndio a visitá-lo. [...] Prosseguiu a cavalo com poucos companheiros, quando o general mandou que deixassemas armas. - Por quê? - perguntou o índio - se o general e sua gente estão armados? [...] Quando o intérprete pediu a Sepé que se apeasse para beijar a mão do general, retrucou o índio: "Ao teu general beijar a mão? Por quê? Acaso estou eu em terra dele e não ele na minha? Dize ao teu general que não me apeio e nem lhe beijo a mão". 
Gomes Freire, com majestade, em sua cadeira, respondeu: "Diga a esse índio que ele é um bárbaro." E este ao pé da letra: "Pois dize-lhe que ele é mais bárbaro que eu."

E depois desse preâmbulo nada cortês, foi dizendo: "Pois, general, eu vim para te dizer que o exército espanhol voltou em paz, e que tu e teu exército façais o mesmo e volteis daqui também! É isto e nada mais o que tenho de te dizer."

Soltou o general umas balandroadas, dizendo que iria até os Povos e que tinha soldados mui bravos. A isso respondeu o índio que também ele tinha soldados que não cediam aos portugueses sem valor. [...]

E, sem mais conversas, disse aos companheiros: "Iá há" - ou seja: Vamos daqui. E dando de esporas aos cavalos, retornaram ao seu acampamento. (Teschauer, 1922, p. 249-250 apud Bernardi, 1980, p. 24-25).

Outro elemento significativo da lenda de Sepé é o surgimento do "Rio das Lágrimas", episódio que delega ao índio poderes sobrenaturais.

Quando Sepé e seus companheiros guaranis foram vencidos na luta na serra do Batovi contra os exércitos lusos e espanhóis, Sepé retirou-se para coxilha do Maricá, e ali, sobre uma rocha, chorou copiosamente de dor pelos companheiros mortos. Chorou dia e noite sem parar. Suas lágrimas molharam a terra, surgindo um filete de água. Quando o sol voltou a brilhar o filete se transformara num arroio de águas cristalinas. Os índio beberam ajoelhados e notaram que tudo se modificava: os pássaros bebiam e cantavam sem parar. As árvores brotavam e os indígenas sentiram nova disposição para a luta. Sepé Tiaraju que chorou por sua guerra e por sua gente, batizou o arroio de Chereça I apaqui... - Chereça! (Rio das Lágrimas que eu verti... - Rio das Lágrimas).Até hoje o pequeno afluente do rio São Sepé continua correndo. (Spalding apud Flores, 1996, p. 134-137).

Um último episódio, e o mais importante, é o que relata o momento em que Sepé morre lutando contra os exércitos de Espanha e Portugal pela terra de seu povo, é santificado e torna-se, então, um herói na literatura do folclore rio-grandense.

As versões mais ricas em detalhes sobre esse episódio da lenda são: os poemas O Uraguai, de Basílio da Gama e O Lunar de Sepé, de Simões Lopes 
Neto; o resumo que Barbosa Lessa faz dos escritos de Manoelito de Ornellas; os relatos da expedição do padre Teschauer, citadas por Moacir Flores; e o livro O Primeiro Caudilho Rio-Grandense, de Mansueto Bernardi, que cita o historiador Robert Southey.

Organizando uma tabela que nos permita visualizar, nas diferentes narrativas, a repetição das situaçóes, teríamos as versões assim ordenadas, conforme a relação sincrônica (horizontal) e diacrônica (vertical) que estruturam um mito (Lévi-Strauss, 1975).

\begin{tabular}{|c|c|c|c|c|c|}
\hline & $\begin{array}{l}\text { Basilio da } \\
\text { Gama } \\
\text { poema O } \\
\text { Uraguai } \\
\text { data: } 1789\end{array}$ & $\begin{array}{l}\text { Simões Lopes } \\
\text { Neto } \\
\text { poema O } \\
\text { Lunar de } \\
\text { Sepé } \\
\text { data: } 1913\end{array}$ & $\begin{array}{l}\text { Barbosa } \\
\text { Lessa } \\
\text { resume } \\
\text { Manolito de } \\
\text { Omellas } \\
\text { data: } 1945\end{array}$ & $\begin{array}{l}\text { Mansueto } \\
\text { Bernardi } \\
\text { dita Robert } \\
\text { Southey } \\
\text { data: } 1965\end{array}$ & $\begin{array}{l}\text { Moacir Fores } \\
\text { cita padre } \\
\text { Teschauer - } \\
1921 \\
\text { data: } 1996\end{array}$ \\
\hline $\begin{array}{l}\text { Características } \\
\text { de Sepé }\end{array}$ & $\begin{array}{l}\text { Fazproezas. } \\
\text { Forçava os } \\
\text { seus com } \\
\text { exemplos e } \\
\text { palavras. } \\
\text { Destro em } \\
\text { atirar, irado e } \\
\text { forte. }\end{array}$ & $\begin{array}{l}\text { Valente } \\
\text { guerreiro. Em } \\
\text { meio aos } \\
\text { perigos, } \\
\text { sempre } \\
\text { andava } \\
\text { primeiro. } \\
\text { Erredava os } \\
\text { inimigos com } \\
\text { o saber das } \\
\text { a ranhas. }\end{array}$ & $\begin{array}{l}\text { "O Gênio da } \\
\text { guerra". Luta } \\
\text { como um ser } \\
\text { sobrenatural. }\end{array}$ & $\begin{array}{l}\text { Homem tão } \\
\text { sagaz quão } \\
\text { destemido; o } \\
\text { único caudilho } \\
\text { que algum } \\
\text { talento militar } \\
\text { desenvolvia e } \\
\text { que nunca } \\
\text { expunha sua } \\
\text { gente. }\end{array}$ & \\
\hline $\begin{array}{l}\text { O(s) inimigo(s) } \\
\text { de Sepé }\end{array}$ & $\begin{array}{l}\text { "O nosso } \\
\text { útimo rei e o } \\
\text { rei de } \\
\text { Espanha". } \\
\text { O govema dor } \\
\text { de Montevidéu. }\end{array}$ & $\begin{array}{l}\text { "Armas de } \\
\text { Castela" que } \\
\text { vinham do mar } \\
\text { do além e de } \\
\text { Portugal. }\end{array}$ & $\begin{array}{l}\text { Exércitos } \\
\text { ibériœs. } \\
\text { Armas de } \\
\text { Espanha e } \\
\text { Portugal. } \\
\text { Gomes Freire. }\end{array}$ & $\begin{array}{l}\text { Governador de } \\
\text { Montevidéu, } \\
\text { José Joa quim } \\
\text { Viana e } 800 \\
\text { homens. }\end{array}$ & $\begin{array}{l}\text { Os } \\
\text { castelhanos. }\end{array}$ \\
\hline $\begin{array}{l}\text { Pelo que } \\
\text { lutava Sepé / a } \\
\text { quem defendia }\end{array}$ & $\begin{array}{l}\text { Terra dos Sete } \\
\text { Povos, que } \\
\text { diża ter } \\
\text { recebido de } \\
\text { "seus } \\
\text { antepassa dos- } \\
\text { ". Defende } \\
\text { "Deus e a } \\
\text { Pátria", não } \\
\text { aceita jugo } \\
\text { "que não seja } \\
\text { o do céu, por } \\
\text { mão dos } \\
\text { padres". }\end{array}$ & & $\begin{array}{l}\text { Em defesa de } \\
\text { sua honra, de } \\
\text { seu povo e de } \\
\text { suas terras. }\end{array}$ & $\begin{array}{l}\text { Terras, } \\
\text { dependentes } \\
\text { da redução de } \\
\text { São Miguel, } \\
\text { que tinham } \\
\text { recebido de } \\
\text { Deus. }\end{array}$ & $\begin{array}{l}\text { Sepé afimava } \\
\text { que as terras } \\
\text { de Santa Tecla } \\
\text { faziam parte } \\
\text { da estância } \\
\text { dos } \\
\text { miguelistas e } \\
\text { foram dadas } \\
\text { por Deus aos } \\
\text { índios. }\end{array}$ \\
\hline
\end{tabular}

Debates do NER, Porto Alegre, ANo 5, N. 5, P. 31-56, Junho 2004 


\begin{tabular}{|c|c|c|c|c|c|}
\hline & $\begin{array}{l}\text { Basíli o da } \\
\text { Gama }\end{array}$ & $\begin{array}{l}\text { Simões } \\
\text { Lopes Neto }\end{array}$ & $\begin{array}{l}\text { Barbosa } \\
\text { Lessa }\end{array}$ & $\begin{array}{l}\text { Mansueto } \\
\text { Bernardi }\end{array}$ & Moaci r Flores \\
\hline $\begin{array}{l}\text { Como morreu } \\
\text { Sepé }\end{array}$ & $\begin{array}{l}\text { Erra uma } \\
\text { lança contra } \\
\text { o governador } \\
\text { [de } \\
\text { Montevideu]. } \\
\text { É ferido por } \\
\text { um golpe de } \\
\text { lança na } \\
\text { testa e no } \\
\text { peito. Foge o } \\
\text { cavalo } \\
\text { levando } \\
\text { Sepé. O } \\
\text { cavalo cai e } \\
\text { joga Sepé } \\
\text { longe. Sepé } \\
\text { não se rende. } \\
\text { O governador } \\
\text { acerta-o com } \\
\text { uma seta; } \\
\text { com Sepé no } \\
\text { chão, atira } \\
\text { com a } \\
\text { pistola. }\end{array}$ & $\begin{array}{l}\text { "Mas o lunar } \\
\text { de Sepé era } \\
\text { o rasto } \\
\text { procurado..." } \\
\text { Sepé foi } \\
\text { ergui do pelas } \\
\text { mãos do } \\
\text { Deus-Senhor, } \\
\text { que Ihe } \\
\text { marcara na } \\
\text { testa o sinal } \\
\text { de seu } \\
\text { penhor. O } \\
\text { corpo ficou } \\
\text { na terra, a } \\
\text { alma subiu } \\
\text { em flor! }\end{array}$ & $\begin{array}{l}\text { Chega-Ihe } \\
\text { pelas costas } \\
\text { um dragão } \\
\text { português, } \\
\text { que Ihe } \\
\text { aplica um } \\
\text { golpe fundo, } \\
\text { de lança. } \\
\text { Sepé abraça- } \\
\text { se ao } \\
\text { pescoço do } \\
\text { cavalo. Tenta } \\
\text { reti rar. Quase } \\
\text { pendurado ao } \\
\text { estribo, não } \\
\text { resi ste. Viana } \\
\text { chega ao } \\
\text { local onde } \\
\text { ele está } \\
\text { caído, e do } \\
\text { alto de sua } \\
\text { sela despeja } \\
\text { sua pis tola } \\
\text { sobre o } \\
\text { corpo já } \\
\text { quase inerte } \\
\text { de Sepé. }\end{array}$ & & $\begin{array}{l}\text { Numa } \\
\text { emboscada } \\
\text { dos } \\
\text { castelhanos, } \\
\text { estes fizeram } \\
\text { duas } \\
\text { descargas. } \\
\text { Os } \\
\text { missi oneiros } \\
\text { examinaram } \\
\text { os mortos e } \\
\text { identifi caram } \\
\text { o corpo de } \\
\text { Sepé Tiaraju } \\
\text { através de } \\
\text { duas cartas } \\
\text { que } \\
\text { encontraram } \\
\text { em seus } \\
\text { bolsos. }\end{array}$ \\
\hline $\begin{array}{l}\text { A } \\
\text { "santificação" } \\
\text { de Sepé } \\
\text { (presença na } \\
\text { terra após a } \\
\text { morte) }\end{array}$ & $\begin{array}{l}\text { Sepé } \\
\text { aparece no } \\
\text { sonho de } \\
\text { Cac ambo. } \\
\text { "Foge, foge" } \\
\text { dizia Sepé. } \\
\text { Cacambo } \\
\text { ainda lhe } \\
\text { esc uta as } \\
\text { vozes. }\end{array}$ & $\begin{array}{l}\text { Lá das } \\
\text { nuvens, } \\
\text { mandou aos } \\
\text { povos } \\
\text { benção por } \\
\text { meio de seu } \\
\text { clarão. O } \\
\text { lunar na sua } \\
\text { testa tomou } \\
\text { no céu } \\
\text { posição e } \\
\text { tomou-se o } \\
\text { Cruzeiro do } \\
\text { Sul! }\end{array}$ & $\begin{array}{l}\text { Os índios } \\
\text { vêem no } \\
\text { espaço, } \\
\text { coberto pela } \\
\text { lua, uma } \\
\text { figura de } \\
\text { sombra, } \\
\text { galopando } \\
\text { um cavalo de } \\
\text { fogo, com } \\
\text { uma lança } \\
\text { vemelha à } \\
\text { destra. "E o } \\
\text { lunar na sua } \\
\text { testa tomou } \\
\text { no c éu } \\
\text { posi ção... } \\
\text { (São as } \\
\text { quatro } \\
\text { estrelas do } \\
\text { Cruzeiro do } \\
\text { Sul). }\end{array}$ & & $\begin{array}{l}\text { Sepé subi u } \\
\text { ao céu } \\
\text { galopando } \\
\text { num cavalo } \\
\text { de fogo, } \\
\text { envolto numa } \\
\text { luz brilhante } \\
\text { indo ao } \\
\text { encontro de } \\
\text { Tupã. O herói } \\
\text { se } \\
\text { trans formou } \\
\text { em santo. } \\
\text { Di zem que na } \\
\text { hora do } \\
\text { meio-dia ele } \\
\text { surge num } \\
\text { cavalo } \\
\text { tordilho } \\
\text { tocando os } \\
\text { animais no } \\
\text { pasto. }\end{array}$ \\
\hline
\end{tabular}

Debates do NER, Porto Alegre, ANo 5, N. 5, P. 31-56, Junho 2004 
Entendemos que esse mito está imerso em uma teia de significados que é explicitada através das características atribuídas à figura de Sepé e sua história. Vemos, por exemplo, que ele possui elementos relacionados à gauchidade. Sepé é "gaúcho" por ser um "índio guarani”, por ter destreza ao montar um cavalo, por possuir espírito de luta e habilidade para guerra, e, também, por sua história se passar na região das Missões - local ligado ao mito de origem do Estado do Rio Grande do Sul.

Elementos religiosos também estão presentes no mito. Sepé é marcado ao nascer com um lunar ou cruz na testa, o que o torna um "escolhido por Deus" ("então Sepé foi erguido pelas mãos de Deus Senhor, que lhe marcara na testa o sinal de seu penhor"). Ao subir aos céus, Sepé torna-se san to e é incorporado ao catolicismo popular. É então elevado à condição de "ser sobrenatural" quando, após sua morte, retorna à terra mediante aparições em público.

Questôes políticas também se fazem presentes nesse mito, pois o que temos em discussão, na guerra travada por Sepé, é "a defesa da propriedade da terra”. Sepé diz-se o dono originário daquelas terras (dadas a ele por Deus e São Miguel), e é assim, portanto, que legitima sua luta.

O mito conta que Sepé lutou contra os exércitos de Espanha e Portugal. Em algumas versões sua morte é atribuída ao ataque de um "dragão português" que o teria matado com sua lança. Em outras ele teria sido morto pelo governador de Montevidéu. Esses episódios aparecem num contexto discursivo que remete à discussão sobre a brasilidade de Sepé Tiaraju, questão que vai além dos objetivos aqui propostos. ${ }^{14}$ No entanto, seria necessário observar que as discussões em torno da legitimação ou não de Sepé Tiaraju como sendo "brasileiro" estavam, no momen to da elabor ação desta pesquisa, voltadas para o cenário político do mandato de Olívio Dutra no governo do estado. ${ }^{15}$ Como nos relata Antônio Cechin,

${ }^{14}$ Discuto a questão da brasilidade de Sepé em meu trabalho de conclusão do curso de Bacharelado em Ciências Sociais (Rosário, 1999).

${ }^{15}$ Olívio Dutra foi eleito, pelo PT, governador do Estado do Rio Grande do Sul, em 1998. Essa entrevista com Antônio Cechin foi realizada nos primeiros meses de seu mandato, em 1999. 
Sepé é perigoso porque está ligado a estes acontecimentos, mas agora o Olívio vai sanar este problema... [...] porque nós já decidimos com o MST que vamos levantar um monumento, um memorial das lutas pela terra em Encruzilhada Natalino. Então já acertamos com o governo do estado com a desapropriação de 25 equitares lá na Encruzilhada e a primeira coisa que será feita é um memorial a Sepé Tiaraju. ${ }^{16}$

Analisando os poemas e canções de autores do folclore gaúcho, como Simões Lopes Neto e Basílio da Gama, percebemos que eles misturam elementos católicos, políticos e também étnicos ao descrever SepéTiaraju como herói da história do Rio Grande do Sul. Nestes, Sepé Tiaraju, além de "santo" e herói, torna-se um mártir, o primeiro a morrer lutando contra os "opressores" pela propriedade da terra no Rio Grande do Sul. Na Romaria da Terra esses elementos estão presentes, embora o sentido e a reapropriação que os seus agentes vão fazer deles sejam significativamente diferentes. Vejamos, então, como o mito do Sepé Tiaraju é reinventado pelas lideranças da Romaria da Terra, e também como essa reinvenção está presente na performance do ritual.

\section{A REINVENÇÃO DO MITO DE SEPÉ TIARAJU NA ROMARIA DA TERRA}

A canção folclórica Missões dos Sete Povos foi um dos temas musicais executados pelos participantes do MST para animar a viagem de volta da romaria de 1999. Nessa canção Sepé adquire poderes sobrenaturais; é predestinado, marcado com uma cruz na testa que, após a sua morte, vira o Cruzeiro do Sul.

\footnotetext{
${ }^{16}$ Segundo Antônio Cechin, esse memorial contará com a assessoria de Oscar Niemeyer e Xico Stockinger, e terá um museu das lutas pela terra, uma espécie de santuário para os mártires e plantas nativas da região.
} 
Missões dos Sete Povos

Nas missões dos Sete Povos nasceu um dia Sepé Trazendo uma cruz na testa, cicatriz sinal de fé Quando o sol batia nele esta cruz resplandecia Por isso lhe deram o nome Tiaraju a luz do dia

Quando o exército da Espanha e Portugal chegou aqui Pra expulsar os Sete Povos toda gente Guarani Tiaraju que era cacique reuniu os seus guerreiros E sem medo dos canhões atacou só com lanceiros

Tiaraju morreu peleando no Arroio Caiboaté Mas depois noutro combate todos viram São Sepé Que vinha morrer de novo junto a gente Guarani Pra embeber seu sangue todo neste chão onde eu nasci

Mais um valente guerreiro a morrer pelo seu pago É por isso que seu nome pro Rio Grande é sagrado São Sepé subiu pro céu, sua cruz ficou no azul Cai a noite ela rebrilha, ele é o Cruzeiro do Sul (grifo meu).

A CPT traz sua versão do mito num folheto da primeira romaria. No documento destacam-se duas figuras: Sepé Tiaraju e Padre Roque González. Sepé Tiaraju é apontado como "o chefe missioneiro de São Miguel”, é o índio-símbolo da luta pela sobrevivência de 478 anos dos povos indígenas, assassinado em 1756 pela aliança dos conquistadores espanhóis e portugueses. Roque González é o jesuíta fundador das reduçōes de São Nicolau, Candelária e Assunção de Pirapó, também assassinado, mas por um índio, em 1628. Dizia no documento:

Sepé lançou-se contra os exércitos de Espanha e Portugal, em defesa desesperada das Missōes. Seu grito de guerra: "Esta Terra tem dono! Recebemola em confiança de Deus e São Miguel! E somente eles nos podem deserdar!" 
Hábil estrategista que era, viu logo a inutilidade do confronto direto. Partiu para guerrilha. Ao emboscar um pelotão inimigo, seu cavalo falseou o pé num buraco. Na queda foi lanceado por um soldado português. Levantavase novamente quando foi prostrado por um tiro partido de Gonçalves Viana, comandante espanhol.Foi a 7 de fevereiro de 1756 que "tomou no céu posição!". Três dias depois, os invasores chacinavam seus 1.500 índios companheiros, nos campos de Caiboaté. São Sepé Tiarajué santo popular no sul. [...]

Roque González, jesuíta trazido por Nenguiru - cacique geral do Uruguai e do Tape, fundou as reduçõesde São Nicolau, Candelária e Assunçãodo Pirapó. Os portugueses, então, já subiam o rio Jacuí em navios menores, aprisionavam índios que levavam como escravos para navios maiores ancorados no mar. A $1^{\circ}$ de novembro de 1628, ajudados pelos índios, Roque e seu colega Afonso Rodriguez ergueram a cruz de uma nova redução no Caaró. No dia 15, quando Roque ajeitava a corda no campanário de 17 metros, levantado pelos índios, foi abatido por um golpe de itaiçá. Afonso foi morto quando tentava socorrer. Dois dias depois, a 17 de novembro, foi trucidado João de Castilhos, no Pirapó.

Os três mártires rio-grandenses morreram nas mãos do próprio índio, vítimas da injustiça que o sistema de colonialismo, implantado pelo europeu invasor, gerava, e com o qual os missionários, contra a sua vontade,foram identificados. (CPT/RS, 1978, grifo meu).

Ao unir a história de Sepé a de Roque González, poderíamos interpretar que a CPT aproxima o padre do índio e torna este último tão importante quanto Sepé nas lutas pela terra, incluindo-o no "mito de origem" da romaria. No entanto, o que se observa na memória coletiva dos participantes da romaria com quem conversamos e que entrevistamos é somente a figura de Sepé Tiaraju. Elton, romeiro da terra há muitos anos, nos relata da seguinte forma o surgimento da Romaria da Terra:

[...] No início a Romaria da Terra não tinha este nome, tinha o nome de Romaria dos Mártires da Terra, porque Sepé Tiaraju foi morto exatamente no dia 7 de fevereiro de 1756, e era uma terça-feira de Carnaval [...]. 
Se compararmos essas duas versões do mito - a canção e o folheto da CPT - vemos que Sepé é "santo" em ambas as narrativas. O que mostra que a CPT está assumindo a religiosidade popular, expressa na música folclórica. Também em ambas as passagens, temos a frase "Esta terra tem dono", elemento legitimador da propriedade da terra.

Enquanto, na poesia, Sepé morre e "embebe seu sangue no chão", na versão da CPT temos esse mesmo elemen to na "martirização" desse índio, que ten do "morrido pelo seu povo", é identificado como "santo" e torna-se mais um mártir da Teologia da Libertação. É esse relato, em que se misturam as figuras de Sepé e dos mártires rio-grandenses, que permite a incorporação do herói popular como santo pelo catolicismo e o enraizamento dos santos oficiais na cultura popular.

Vemos também a utilização de elementos como "guerrilha" e "confronto direto", código de linguagem que "politiza" a figura do índio, trazendo-o para o contexto atual das lutas no campo.

Sepé Tiaraju, ao contrário do que queriam racionalistas, como Moysés Vellinho, virou mito. Mas não um mito que veio "alienar" a história do Rio Grande do Sul com suas "superstições" e "lendas" - o que temiam esses in telectuais - mas um "mito das lutas no campo".

Quando analisamos as versões mais recentes do mito de Sepé Tiaraju, encontradas no CD Arte em Movimento, do MST (1997) e no livro Queremos Reforma Agrária, de Adão Pretto (1987) - então deputado federal pelo PT e prosador da Romaria da Terra -, vemos que esses autores, ao reinventarem o mito de Sepé Tiaraju em suas músicas e prosas, apropriamse da figura desse "herói santificado" como uma das maneiras de legitimarem sua luta pela terra no Rio Grande do Sul.

Nestas versões vemos que Sepé Tiaraju é um símbolo da luta pela terra, é o primeiro herói de uma história "inventada" das lutas pela terra no campo. Um primeiro dado que nos demonstra essa idéia é a própria construção dos "temas" e "lemas" da Romaria da Terra, desde seu início até os dias de hoje. Podemos dizer que estes se concentraram principalmente em três momentos: um primeiro momento em que o foco da romaria, como já mencionamos, é centrado na questão indígena com o martírio do povo 
Guarani no nosso estado. Um segundo momento, no qual as questões giravam em torno dos conflitos no campo, decorrentes das ocupações de terra, principalmente as do MST. E, mais recentemente, um último, em que a problemática da romaria tem se centralizado nas dificuldades encontradas nos assentamentos, tornando-se o foco de discussão a agricultura familiar e a agroecologia.

Se analisarmos esses temas, notamos que eles simbolizam uma cronologia das lutas pela terra no estado. História essa que teria início nas guerras guaraníticas, tendo como continuidade as lutas dos sem-terra. Acreditamos que a cronologia desses temas esteja colaborando na construção desta "história inventada das lutas no campo", que é in corporada à memória coletiva dos atores dessa romaria como a sua própria história.

É de extrema relevância notarmos que as Romarias da Terra tenham tido como tema de fundação exatamente uma homenagem a Sepé Tiaraju, uma figura das Missões, que, por sua vez, é espaço de lutas que constroem o mito de origem do Rio Grande do Sul, pois, como nos demonstra Hobsbawm (1997), na invenção de uma tradição tenta-se, sempre que possível, estabelecer "uma continuidade com um passado histórico apropriado". Que passado mais significante poderiam as lideranças da romaria encontrar para simbolizar a "origem das lutas pela terra no Rio Grande do Sul" do que um índio Guarani missioneiro?

No ritual da Romaria da Terra, um momento esperado, como já mencionamos, é a famosa "trova" de Adão Pretto, que é cantada, no palco, junto com outros artistas convidados. Analisando alguns de seus poemas encontramos dois: Ruinas de São Miguel e A Verdadeira História dos Indios do Rio Grande, que incorporam a luta de Sepé Tiaraju à luta dos romeiros da terra. O primeiro começa descrevendo as ruínas de São Miguel e relatando como viviam "em paz" os Sete Povos, para acabar com a chegada dos europeus e a morte de Sepé. Os versos finalizam com Adão Pretto se dirigindo ao "seu povo", ou seja os "oprimidos do campo". A trova ilustra a "caminhada", desde os índios com Sepé, até os dias de hoje, com os semterra. Seus trechos finais são os mais significativos (Pretto, 1997, grifo meu): 
[...] É um templo majestoso ${ }^{17}$

Feito com a força da união

[...] Aquele templo retrata

O grande amor pelo chão

Deixa o cristão comovido

Onde Sepé foi vencido

Pela força da ambição

[...] Numa queda de Sepé

Lhe atingiram de traição

Num golpe tão de repente

Tombava o índio valente

De lança firme na mão.

Numa derrota que encerra

Entre índios que peleavam

Viram Sepé que gritava

Que eram os donos da terra.

[...] Meu povo trabalhador

Quero que fique sabendo

A história de Tiaraju

Em meus versos vou dizendo

Ele morreu pela terra

E seu povo defendendo

Alerta pra povo meu

O que Tiaraju sofreu

Hoje nós estamos sofrendo.

Finalmente, uma das músicas do CD Arte em Movimento, de Zé Pinto, (MST, 1997, grifo meu) também ilustra com clareza nossa hipótese:

A invasão chegou de barco nesta América Latina

[...] Nos pelourinhos da morte tanto sangue derramado

${ }^{17}$ Adão Pretto refere-se, aqui, aos Sete Povos das Missōes antes dos "in vasores" ch egarem, ou seja, antes do Tratado de Madri.

Debates do NER, Porto Alegre, ANo 5, N. 5, P. 31-56, JUnho 2004 
Pra mão-de-obra índio e negro escravizados

São três histórias neste grande continente

Uma bem antes dos invasores chegarem

E a segunda cinco séculos de invasão

E a resistência india-negra e popular

E a terceira é a que vamos construindo

Pra destruirmos todo mal

[...] Levanta indio junto aos outros companheiros

Vamos ligeiros contra a força desse mal [...]

Essas narrativas demonstram como os atores da romaria estão se apropriando do mito de Sepé Tiaraju. Nelas, a Guerra Guaranítica representa o mito de origem das lutas no campo no Rio Grande do Sul, e Sepé torna-se o herói de uma classe social, a classe dos "oprimidos do campo".

Como nos coloca Lévi-Strauss (1975, p. 65), "o objetivo do mito é fornecer um modelo lógico para resolver uma contradição". Sendo assim, o mito de Sepé, ao criar uma coesão dos atores da Romaria da Terra como pertencentes a uma mesma história, estaria resolvendo conflitos sociais de cunho étnico, religioso e político, que podem estar latentes nessa romaria.

Conflitos raciais tornam-se "amenizados", pois pessoas de diferentes etnias, presentes nesse ritual, ao identificarem-se como originárias de um mesmo mito indígena que está representando os "oprimidos do campo", tornam-se parte de uma mesma classe social que as homogeneíza. No âmbito do religioso, um índio pode tornar-se santo popular, pois é apropriado como mártir pela Teologia da Libertação. No nível do político, os conflitos entre comunidades indígenas e MST são simbolicamente apaziguados pela aceitação de Sepé como "legítimo dono da terra", pois é seu habitante originário. 


\section{CONSIDERAÇÕES FINAIS}

Nesta ritualização das "lutas no campo", performada na Romaria da Terra, é construída, na dimensão do simbólico, uma narrativa que está "inventando" uma "única história" de todos os conflitos pela posse da terra no Rio Grande do Sul. Essa "história inventada", que teria seu "mito de origem" nas lutas indígenas em defesa da terra - que se deram na região das Missōes e tiveram como seu mártir e "herói fundador", Sepé Tiaraju - e sua continuidade nas lutas dos quilombos, chegando até os dias de hoje com as lutas no campo dos colonos do MST.

Como nos coloca Hobsbawm, toda "tradição inventada" não é inventada por acaso. Há sempre um fim. E aqui nós entendemos que ao fazer uma releitura, uma reinvenção do mito de Sepé Tiaraju, os atores da Romaria da Terra - como o MST, a CPT, o PT, e outros - estariam incorporando a guerra guaranítica pela propriedade da terra ${ }^{18}$ à sua própria história, e, assim, legitimando as ocupações de terra no Rio Grande do Sul.

Um outro aspecto dessa "história inventada" é a presença do índio (Sepé), do negro (quilombos) e do trabalhador rural popular (colonos semterra) como sujeitos de uma mesma trajetória histórica. Portanto, esses sujeitos também estão nos "dizendo" que são "todos iguais", todos são "oprimidos", seja pelo "colonizad or", seja pelo "latifundiário", e, sendo assim, a Romaria da Terra também se torna um espaço onde é explicitada e performada a "lu ta de classes" de nossa sociedade.

Nessa construção de uma "unidade dos oprimidos do campo" são explicitados valores como "uniāo", "coletividade" e "solidariedade" e padrões de comportamento como o "lutar pelos direitos" e a "defesa e união dos oprimidos". Noções de pertencimen to à terra elaboradas por esses sujeitos - seja por "direito divino", "originário" ou "de necessidade" - tornam-se discursos étnico-político-religiosos de legitimação da propriedade da terra.

${ }^{18} \mathrm{O}$ elemento indígena incorporado traz como discurso legitimador da posse da terra o "ser originário". "Esta terra tem dono!", dizia Sepé. 
O elemento étnico, nesse trabalho, é colocado como uma questãochave para compreensão da reinvenção do mito de Sepé Tiaraju na Romaria da Terra. O índio é o "verdadeiro dono da terra" e, sendo assim, a figura de Sepé, ao ser incorporada à identidade de colonos sem-terra e reinventada como o mito de origem das batalhas no campo no Rio Grande do Sul, torna-se elemento central de legitimação das lutas pela propriedade da terra do MST - questão central da romaria.

O caráter político da romaria é evidente, uma vez que esta tem como tema as lutas das minorias, dos oprimidos. Nela é discutida e explicitada a luta de classes da nossa sociedade. Seus "peregrinos" pertencem a entidades e movimentos sociais como o MST, a CUT, o CIMI, etc. Já o elemento religioso é explicitado na romaria através do discurso da Teologia da Libertação, que entende a terra como uma dádiva divina a que todos têm direito.

Sendo assim, a reinvenção do mito de Sepé Tiaraju na Romaria da Terra, além de unir o passado, o presente e o futuro das histórias dos atores desta romaria - através da construção desta narrativa - também tem a tarefa de resolver contradições que estão latentes na romaria. Nesse sentido, questôes como conflitos de caráter étnico existentes entre índios e colonos são homogeneizadas numa mesma classe social. As ocupações de terras são legitimadas com a presença do índio na origem dos colonos.

Todas essas característi cas da romaria estão explicitadas tanto nos discursos de seus participantes como na própria performance do ritual que, como vimos, condensa uma diversidade de elementos de diferentes esferas, como o estandarte com a figura de Sepé Tiaraju, bandeiras, faixas e bonés do MST e do PT, assim como a presença e os discursos de políticos e religiosos.

Esses sistemas de valores e padrões de comportamento, ao nosso ver, têm como objetivo unir todos os participantes da romaria em um só "coletivo" e construir a identidade política e religiosa de seus participantes. Em eventos como a Romaria da Terra, os símbolos e práticas rituais, historicamente originais e livremente inventados, são meios importantes através dos quais os grupos sociais constroem sua identidade e conquistam seu espaço na sociedade. 


\section{REFERÊNCIAS}

MST. Arte em movimento. 1997. 1 CD.

BERNARDI, Mansueto. O primeiro caudilho rio-grandense: fisionomia do herói missioneiro Sepé Tiaraju. Porto Alegre: Escola Superior de Teologia São Lourenço de Brindes: Livraria Sulina Editora, 1980.

CPT/RS. Primeira Romaria da Terra. 1978. Folheto. 1995.

Romaria da Terra: os pequenos da terra a caminho com Deus.

.20 anos de Romariasda Terra no RS: momentosfortes de celebração da vida dos trabalhadores e reforço à Reforma agrária. Voz da Terra, ano 17, n. 64, jan./fev. 1997.

Agricultura familiar. resistência e alternativa para o Brasil. 1998. Texto-base da $21^{\text {a }}$ Romaria da Terra.

. Agricultura familiar: trabalho,organização e conquista.1999. Textobase da $22^{\text {a }}$ Romaria da Terra.

FLORES, Moacir. Colonialismo e missões jesuiticas. Porto Alegre: Ediçōes EST, 1996.

GAMA, Basílio da. O Uraguai. In: SILVA, Camarinha da. Basílio da Gama: O Uraguai. Rio de Janeiro: Livraria Agir Editora, 1964. (Nossos Clássicos, n. 77).

GOES, Cesar. B. A Comissão Pastoral da Terra: história e ambivalência da ação da Igreja no RS. Tese (Doutorado em Antropologia Social)-PPGAS, Universidade Federal do Rio Grande do Sul, Porto Alegre, 1997.

HOBSBAWM, Eric. In trodução: a invenção das tradições. In: HOBSBAWM, E.; RANGER, T. A invenção das tradiçôes. Rio de Janeiro: Paz e Terra, 1997. p. 9-24. 
HOFFMAN, Leandro S. N. A cruz e a bandeira: a construção do imaginário dos sem-terra do RS 1981/1987. Dissertação (Mestrado em História)PPGH, Universidade Federal do Rio Grande do Sul, Porto Alegre, 1997.

LÉVI-STRAUSS, Claude. A estrutura dos mitos. In: Antropologia estrutural. Rio de Janeiro: Tempo Brasileiro, 1975. p. 237-266.

NAVARRO, Zander. Desenvolvimen to agrário, movimentos sociais e os assentamentos rurais. o caso do Rio Grande do Sul. Porto Alegre, 1997. Mimeografado.

NOVAES, Regina Reyes. De corpo e alma: catolicismo, classes sociais e conflitos no campo. Rio de Janeiro: Graphia, 1997.

OLIVEN, Rubem. A parte e o todo: a diversidade cultural no Brasil-Nação. Petrópolis: Vozes, 1992.

PRETTO, Adão. Queremos reforma agrária. Petrópolis: Vozes, 1987.

ROSÁRIO, Valéria Aydos. A reinvenção de mitos e tradiçôes missioneiras na Romaria da Terra, RS: o mito de Sepé Tiaraju. Monografia (Bacharelado em Ciências Sociais)-IFCH, Universidade Federal do Rio Grande do Sul, Porto Alegre, 1999.

SANTOS, José Vicente Tavares dos. Lutas agrárias e cidadania. In: VIOLA, E. J.; SCHERER-WARREN, I.; KRISCHKE, P. (Org.). Crise politica, movimentos sociais e cidadania. Florianópolis: Editora da UFSC, 1989. p. 75-89.

SANTOS, J. V. Tavares dos; BELLONI, I.; LACROIX, B. M. (Org.). A questão da terra. Porto Alegre: Comissão de Agricultura e Pecuária da Assembléia Legislativa do Estado do Rio Grande do Sul, 1981.

STEIL, Carlos. O sertão das romarias. Petrópolis: Vozes, 1996.

TURNER, Victor. Pilgrimage as social process. In: Dramas, fields and metaphors. Ithaca: Cornell University Press, 1974. 